\title{
International and Global Issues
}

\author{
Amelia King-Kostelac \\ The University of Texas at San Antonio \\ David Hòa Khoa Nguyen, J.D., Ph.D. \\ Indiana University - Purdue University Indianapolis (IUPUI)
}

\section{Introduction}

Globalization has been one of the most powerful change agents at work in the twenty-first century. Within higher education, this has meant numerous important shifts: changes in curriculum to serve new student populations and emerging economic and technological demands; shifts in funding and organizational structures; and new competitive pressures, often paired with a paucity of resources. Laws in other countries and international treaties are important to consider as students, faculty, and staff are more mobile today than ever.

As students and faculty travel, and institutions engage in business transactions and establish educational programs in foreign countries, legal issues arise. For example, potential liability issues may arise in study-abroad or exchange programs. As students, faculty, and staff are traveling, institutions should understand both their home country's laws and foreign laws to take reasonable steps to protect their students and faculty, and conduct due diligence to assess risks and address those concerns. Some concerns with studying abroad may be political unrest, underage consumption of alcohol or other controlled substances, or challenges participating fully as a result of a disability.

This chapter offers an overview of international legal issues that are pertinent to the policies and operation of universities within the United States, first providing a general background for key historical and contemporary social and political issues pertinent to understanding the ways in which globalization has influenced higher education in the United States, and secondly, examining the laws impacting international higher education, domestic students studying abroad, and international students studying in the U.S.

\section{Historical and Social Context}

Although the second half of the twentieth century was marked by a trend toward an opening of national borders and an increase in international trade and complex interconnectedness between nations' economies, this trend argu- 
ably has its roots in political and economic trends stretching well back into the colonial era, including economic expansion of major colonial powers into other sovereign nations in Africa, North and South America, and Asia (particularly Southeast Asia and the Pacific Islands). The power relationships established in this early period laid the groundwork for further U.S. and European military expansion and economic imperialism in the eighteenth and early nineteenth centuries. Without the economic activities and resources provided to Western and European nations - including the use of slave labor and access to natural and mineral resources from colonized lands - it is hard to imagine how an equivalent amassing of wealth and resources among a finite number of European nations would have occurred. In fact, many historians now accept that what we commonly call "Modernism" is, in reality, an ideology with its origins in Enlightenment Europe, rising alongside capitalism and largely in response to the economic and resource prosperity created by colonization and slavery.

Neither the Industrial Revolution nor modernisms ${ }^{1}$ writ large would have come to exist as they did without the earlier impact of colonialism on the borders and economic prosperity (or lack thereof) of modern nation states. ${ }^{2}$ As these changes in labor and living conditions caused shifts in populations from rural areas to (increasingly large) urban cities, they also began to precipitate social revolutions throughout the eighteenth and nineteenth centuries, which led to the emergence of democracies as a new system of political governance. By the twentieth century, nations were deeply entangled in one another's economic activities. In Europe, increasingly conservative nationalist and populist political movements led to the rise of socialist and fascist governments, while elsewhere across the globe, current and former colonial nations continued to fight for economic and political independence. After World War II, these trends coalesced into what is more commonly recognized as the beginning of globalization. Globalization in the late twentieth and early twenty-first century has been driven by the reemergence of nineteenth-century laissez-faire, free-market capitalism, which has further encouraged the interdependence of the world's economies, cultures and populations; often in such ways that have privileged the culture and economic might of former colonial nations of Western Europe

1 See generally Peter Brooker, Andrzej Gasiorek, Deborah Longworth \& Andrew Thacker, THE OXFoRd HANDBOOK OF Modernisms (2010). Modernisms/modernities are terms which recognize the disparate, variable ways in which this phenomenon has evolved in different spaces across the globe; they offer an alternative to the more monolithic Modernism/Modernity, which centers European modernism, both historically and ideologically. For further reading discussing the general impact of these historical influences on higher education, see generally John R. Thelin, A History of American Higher Education (3rd ed., 2019), and Craig Steven Wilder, Ebony AND Ivy (2014), among others.

2 As an example, consider that boundaries of a majority of African nations were formalized by European colonial powers at the Berlin Conference (1884-85), when major colonial powers met to determine boundaries for African nations so as to limit fighting between themselves over said territories. French, Belgian, German, British, Spanish, Italian and Portuguese colonial powers together determined the names and specific borders for most states. See Martin Shanguhyia \& Touin Falola, The Palgrave Handbook of African Colonial and Postcolonial History (2018); Olufemi Taiwo, How Colonialism Preempted Modernity in Africa (2010). 
and North America. While by no means the universal economic force, it has greatly shaped law and policy within the U.S. This, in turn, influenced the identity of higher education.

Alongside these broader trends, the post-WWII era was also marked by social movements aiming to increase social and racial equity. In the U.S., the civil rights, women's liberation and gay rights movements all resulted in changes to the nation's legal structure in order to address aspects of discrimination and marginalization due to racial and ethnic identity, gender and sexual orientation, religion, age and disability status. From the 1960s through the 1990s, new laws emerged that have provided greater legal protections to many of these groups, including but not limited to: the Equal Pay Act (1963), ${ }^{3}$ Civil Rights Act $(1964,1991),{ }^{4}$ Age Discrimination in Employment Act (ADEA) (1967), ${ }^{5}$ and Americans with Disabilities Act (ADA) (1990). ${ }^{6}$ As many of the topics covered in this chapter will demonstrate, such legal actions aimed at social equity are by no means universal, nor immutable; however, the ongoing debate on what protections should be provided for individuals within these protected classes have resulted in key legal and policy developments that are central concerns for understanding the challenges U.S. colleges and universities face, both domestically and in their operations and relationships internationally.

The latter half of the $20^{\text {th }}$ century saw an increase in transnational policy organizations and international trade agreements. ${ }^{7}$ As an example, the North American Free Trade Agreement (1994), ${ }^{8}$ or NAFTA, aimed to reduce or eliminate a variety of perceived barriers to trade between the U.S., Mexico, and Canada. This included a variety of embedded agreements regarding environmental, educational, trade and employment policies. It also included increased protections for intellectual property, such that many U.S.-based corporations would be able to more easily exercise proprietary control over various types of software and patents on items such as pharmaceuticals and agricultural products throughout the territory. For colleges and universities, this agreement meant numerous shifts in how transnational relationships and partnerships would be conceived. As higher educational institutions within the U.S. had funding, expenditures and infrastructure which largely dwarfed those

29 U.S. Code Chapter $8 \S 206(d)$.

4 Pub. L. No. 88-352, 78 Stat. 241 (codified as amended in scattered sections of 2 U.S.C., 28 U.S.C., and 42 U.S.C.); Pub. L. 102-166 (1991).

29 U.S.C. $\S \S 621-634$ (2013).

642 U.S.C. $\S \S 12101-12213$ (2013) (amended 2008).

7 See, for example, organizations such as the United Nations (1945) — which replaced the earlier League of Nations (1920-1946) — the International Monetary Fund (1945), the North Atlantic Treaty Organization (1949), the European Union (1993), World Trade Organization (1995) which was preceded by the 1948 General Agreement on Tariffs and Trade (GATT) — and NAFTA (1994).

8 The North American Free Trade Agreement. Jan. 21, 1994. H.R. Doc. No. 103-159, vol. 1. In September 2019 negotiations between the three nations resulted in the drafting of the United States-Mexico-Canada Agreement (USMCA); pending ratification of the agreement in all three nations, NAFTA remains in effect. 
of Canada and Mexico, this created a situation in which institutions within the U.S. were well-positioned to determine the focus and scope of new programs and international relationships that were not as accessible to institutions with less capital, and to do so with guarantees in place that would protect the intellectual property and academic freedom of faculty and students' research.

For the purposes of understanding international legal issues for higher education, these types of agreements are important, as they can shape how issues such as academic freedom ${ }^{9}$ are addressed in different nations. As different nations can have radically different constraints on academic freedom, these types of agreements can determine the degree to which institutions based in the U.S. must be cognizant of ways in which foreign and international laws may differ from national laws protecting intellectual property and faculty and students' speech.

To be clear, globalization and internationalization are not synonymous; however, globalization does provide a great deal of context for increasing international activities and focus in higher education, not the least of which is the prevalence of English as a lingua franca for business, research, and technology sectors, as well as the larger shift of the U.S. away from manufacturing and toward a service- and knowledge-based economy. ${ }^{10}$ Whereas globalization refers to large-scale — often abstract — economic trends, internationalization refers to the specific policy and governance choices that colleges and universities make in response to these global trends.

For colleges and universities in the U.S., internationalization can be split into two general categories: 1) the expansion of higher education institutions into other countries via satellite campuses and partnerships with institutions in foreign countries; and 2) the movement of students internationally via study-abroad programs. Both of these issues are addressed within this chapter, with the primary focus being common legal interests and concerns for U.S. institutions and students in these international settings. Economic shifts have served to increase pressure for higher education to provide more specific jobbased skills and to produce graduates capable of competing in this globally interconnected landscape, which in turn supplies a rationale for the currently robust interest in internationalization within higher education.

\footnotetext{
9 Academic freedom refers to the belief that the strength/health of academe requires that scholars have the freedom to teach or communicate ideas without fear of retaliation (i.e., being fired, persecuted, imprisoned, etc.) for their work. Needless to say, laws protecting academic freedom vary widely across the globe. Within the U.S., it is the basis for providing tenure to faculty; however, it is not without controversy or limitations. For further reading, see generally Akeel Bilgrami \& Jonathan Cole (eds.), Who's Afraid of Academic Freedom? (2015); Timothy Reese Cain, Establishing Academic Freedom: Politics, Principles, and the Development of Core Values (2012); Richard Hofstadter \& Walter P. Metzger, The Development of Academic Freedom in the United States (1955).

${ }^{10}$ Philip G. Altbach \& Jane Knight, The Internationalization of Higher Education: Motivations and Realities, 11 J. of STUdies IN INT'L Ed. 290 (2007).
} 


\section{U.S. Students and Study Abroad}

As noted above, one component of the internationalization of higher education is the movement of students outside national boundaries via study-abroad or certain fellowship programs. ${ }^{11}$ Whether discussing international students studying within the U.S. or the presence of U.S. students in other countries, the experience is largely framed around the noncitizen or "outsider" status of the student. Students studying abroad face a wide variety of issues, both in and outside the classroom, which can be loosely grouped into issues related to student experience as well as security. The former governs the kinds of activities, lodging, and curriculum that a student may experience; the latter refers to the necessity to protect students' physical, emotional, and psychological well-being while abroad, as well as efforts to minimize legal entanglements that may arise due to differences in culture and law in foreign countries. As one might expect, the two domains are thoroughly intertwined, with student safety and well-being tied closely to the quality of activities, spaces, and programming provided.

Travel has long been a part of the college experience for students in the U.S., going back to colonial times when students from wealthy families commonly traveled abroad to Europe for both advanced studies in specific fields (i.e., medicine or law) as well as for cultural and historical insight. Even so, the popularity of such travel ebbed and flowed based on a variety of national economic and social trends. In the period following the American Revolution, and again from end of nineteenth century and up through World War I, many politicians and educational leaders decried study abroad as a sign of cultural dependence or inferiority, arguing instead that students' education should focus on developing skills required for civic duties and economic success within the nation. As noted by Scott, "before it became an international institution the university had first to become a national institution-just as internationalization presupposes the existence of nation states." 12

Nonetheless, the numbers of students travelling abroad gradually increased throughout the $19^{\text {th }}$ century. By the early twentieth century, a wide variety of organizations were engaged in supporting international endeavors, included the establishment of the Rhodes Scholarships (1902) and of organizations such as the American Academy in Rome (1905) and the Institute of International Education (1919). Around this same time period, international students coming to study within the U.S. also began to grow, inaugurating an era of higher education where the flow of students across the globe has become increasingly common and the relationships between higher educational institutions increasingly complex. ${ }^{13}$

11 For example, Fulbright or Rhodes Scholar programs.

12 Peter Scott, The Globalization of Higher Education, 123 (1998).

13 Has de Wit \& Gilbert Merkx, The History of the Internationalization of Higher Education, in The SAGE Handbook of Higher Education, 43 (Darla K. Deardorff, Hans de Wit, John D. Heyl \& Tony Adams eds., 2012). 
In more recent years one can see this trend continuing. From 1996 to 2007, for example, the number of U.S. students studying abroad more than doubled, rising from less than 100,000 to almost a quarter of a million. ${ }^{14}$ As of 2017 , this number has tripled, with over 300,000 U.S. students participating in studyabroad programs in countries across every continent. ${ }^{15}$ Perhaps unsurprisingly, the booming popularity of study abroad has also led to the presence of these programs being viewed as an indicator of institutional quality. The ability of an institution to provide this experience is viewed as a vital way to expose students to opportunities and experiences seen as vital to students' long-term professional success in a globalized world.

Conducting activity abroad may require compliance with licensure and registration with local authorities. Local laws may require the establishment of a separate legal entity, which will have separate tax and business consequences. When entering into business partnerships with foreign institutions or companies, choice-of-law issues may arise if there is a dispute. It is important to examine whether the contract specifies under which country's law the contract will be interpreted. Litigation in a foreign country can look very different; not only the laws, but also the procedures. In addition, hiring foreign employees will require compliance with relevant local employment and tax laws. Different countries may have different requirements unfamiliar to one's home country.

For student affairs professionals and administrators, navigating the legal concerns governing such international activities requires detailed understanding of risk and crisis management practices, including variable levels of legal liability regarding issues such as personal injury and accidental death, appropriate minimum standards, housing, fire safety, unlawful discrimination, sexual harassment and assault, and lack or oversight of medical care. ${ }^{16}$ As the number of students and study-abroad programs grow, the need for infrastructure and staffing to meet these needs has also expanded, leading to the creation of positions like Senior International Officers (SIOs), who seek to oversee both risk management, health and safety support, as well as student affairs and international program administration.

As one might expect, risk management is different from nation to nation, with some locations, such as the U.S., often being described as "risk averse" (aiming to limit or eliminate the potential for certain risks to occur), whereas other nations are known for being more inclined to manage crises as they arise. As noted by Rhodes \& Ludeman: "In some countries, such as the United States, legal issues affect important day-to-day activities of campus administrators, and most faculty and staff are aware of their impact. For them, everyday interaction brings the potential for criminal or civil penalties. In other countries, there may

\footnotetext{
${ }^{14}$ See Institute of International Education (IIE), Open Doors Report (2008), available at http:// www.open-doors.iienetwork.org. Cited in April H. Stroud, Who Plans (Not) to Study Abroad? An Examination of U.S. Student Intent, 14 J. of Studies in InT'L Higher Ed. 491 (2010).

15 IIE, Open Doors Report (2017), available at https://www.iie.org/Research-and-Insights/OpenDoors/Data/US-Study-Abroad.

16 William P. Hoye, Managing Liability: Business and Academic Operations, 11-16 (2008).
} 
be lesser potential for legal action stemming from an institutional environment. In these settings, liability is less of a concern." ${ }^{17}$ That said, U.S. law is now more commonly applied to institutions' activities abroad, particularly in the context of study abroad. This may be at least partially due to the large number of U.S. students enrolling in study-abroad programs, as well as the fact that a large number of international students enroll at U.S. institutions. In any case, the existing predilection toward risk aversion within the U.S. presents student affairs professionals with an exigency to understand the legal risks and liabilities that are commonly faced by their students in international settings, and to have appropriate training/orientation, guidelines, and protocols set forth in advance of any such activities. In fact, legal experts often remind institutions of their duty to provide students participating in study-abroad programs with a reasonable standard of care. ${ }^{18}$

Determining institutional duty of care and legal responsibility can be challenging when colleges and universities contract with third-party vendors as program sponsors. For example, in Paneno v. Centres for Academic Programmes Abroad, Ltd., ${ }^{19}$ a Pasadena Community College student enrolled in a study-abroad program through Centres for Academic Programmes Abroad - USA (CAPA-USA). CAPA-USA, a California corporation, contracted with individual colleges and universities and individual students to provide study abroad services. Paneno entered into a contract with CAPA-USA to participate in a Florence, Italy, study-abroad program and lived in an apartment that was procured by CAPA-USA's parent company CAPA-UK. While in Italy, the student fell six stories after his apartment's balcony railing gave way as he leaned on it. Paneno suffered serious injury resulting from the fall, including paralysis. He initially filed suit against CAPA-USA and Pasadena Community College based on premises liability and negligence. Later, he added CAPA-UK as a defendant in the case after learning of its parent-company relationship. While the trial court dismissed CAPA-UK for lack of personal jurisdiction, an appeals court found there was a sufficiently close relationship between the two companies that it availed itself to the general jurisdiction of California courts, given that its marketing materials attempted to disguise CAPA-UK's responsibility of the program and indicated it could only be sued overseas. This case provides an example how challenging it may be to determine legal responsibility when multiple international parties are involved.

Some of the leading causes of court cases and claims against colleges and universities sponsoring international programs fall into several overarching categories: (1) physical and sexual assault and/or injury (sexual harassment/ assault, personal injury and accidental death, motor vehicle and pedestrian ac-

17 Gary Rhodes and Roger Ludeman, Legal, Health, and Safety Issues: Crisis Management and Student Services in International Higher Education, in THE SAGE HANDBook of Higher Education, 223, 6 (Darla K. Deardorff, Hans de Wit, John D. Heyl \& Tony Adams eds., 2012).

${ }^{18}$ Richard B. Evans. A Stranger in a Strange Land: Responsibility and Liability for Students Enrolled in Foreign-Study Programs, 18 J. Coll. \& Univ. Law 299 (1991).

1913 Cal.Rptr.3d 759 (Cal. Ct. App. 2004). 
cidents); (2) unlawful discrimination; (3) oversight or lack of medical treatment; and (4) lack of due process or unfair dismissal claims. ${ }^{20}$ Since the mid-1990s, instances of colleges being sued for injury or death have increased. Although colleges in these cases have not been treated as the sole insurer of student safety, institutions have been held to a certain degree of duty of "reasonable" care imposed, meaning that they must take steps to protect faculty, students and/or staff from any kind of reasonably foreseeable harm. When the studyabroad program is in a location known to be unsafe (due to political instability, high rates of criminal activity, etc.), this duty increases as the risk increases.

The legal perspective on student experience is largely governed by issues of access and equity; that is, what are the home institution's legal responsibilities to provide access to different kinds of activities while abroad? If, for example, a student with disabilities wishes to participate in a study-abroad program, what obligations does the home institution have to that student? This can be a fairly complex question when one considers the variability of countries that students may visit as a part of a study-abroad program. The following sections tackle some of the most common legal issues faced by U.S. students studying abroad, with a brief overview of the topic and an outline of key cases provided for each.

\section{Assault, Injury and Accidental Death}

Legally speaking, the physical and emotional harm that can be inflicted by incidents of injury or assault comes down to determining whether there has been demonstrable negligence on the part of the university or college in taking steps to mitigate or prevent readily foreseeable risks. Kaplin and Lee offer examples of two cases with differing outcomes to illustrate the boundaries of duty of care for colleges. ${ }^{21}$ In one case a small public college, St. Mary's College of Maryland, settled with three students who, along with two other female students, had been raped after their bus was robbed by armed bandits while studying abroad in Guatemala. ${ }^{22}$ The plaintiffs claimed that the robbery and subsequent rape could have been prevented if the school had provided better security (including providing security services and traveling in a convoy) and had chosen a safer route for travel. Although the college argued that sufficient safety precautions had been taken, and that the events could not have been reasonably foreseen, in light of there having been no prior incidents, they nonetheless settled with the students. In the second case, a student unsuccessfully sued the University of Minnesota after having been assaulted by a taxi driver during a study-abroad program in Cuernavaca, Mexico. The student claimed the university had been negligent in not providing housing closer to classes or providing students with safe transportation; however, the university was not

\footnotetext{
${ }^{20}$ Hoye, supra note 16; Rhodes \& Ludeman, supra note 17.

21 William A. Kaplin \& Barbara A. Lee, The Law of Higher Education, 111-112 (5th ed. 2014).

${ }_{22}$ Beth McMurrie, College Settles Suit by 3 Students Over '98 Attack in Guatemala, Chron. HigHer Ed. (July 5, 2002), available at $\mathrm{http} / / /$ chronicle.com/daily/2002/07/2002070502n.html; see also Kaplin \& Lee, id.
} 
held liable because of a long history of the program operating in the location with no prior assaults (in other words, it could be viewed as an isolated event). ${ }^{23}$

Together, the two cases highlight the unique challenges posed by the student-institution relationship in study-abroad programs. ${ }^{24}$ For many institutions, the logistics challenges of knowing the study-abroad site well enough to provide adequate diligence of care for students outstrips the resources they want to or are able to provide. Thus, many institutions contract with third parties, such as the Institute of International Education (IIE), to provide programming.

While institutions are not currently required to report crime numbers for study-abroad programs as they are for incidents on campus, there has been some pressure over the past several years to bring the on- and off-campus requirements for crime reporting in line..$^{25}$

\section{Medical Access and Care}

While traveling and studying abroad, injuries and accidents are bound to occur. However, in order to receive medical care and treatment, fluency in the local language can be important. Institutional travel and medical assistance coverage that provides faculty, students, and staff with $24 / 7$ access to medical professionals and/or interpreters to talk in the students' native language can help with limiting and preventing liability. In McNeil v. Wagner College, ${ }^{26}$ Eileen McNeil visited a town in Austria as part of her overseas study program arranged by her college. During her visit, she fell on ice and broke her ankle. While receiving treatment at the hospital, the study-abroad program's administrator served as her interpreter. After treatment of her ankle, she suffered permanent nerve injuries. McNeil sued the college based on the claim that its agent, the program's administrator, did not inform her that the local physician recommended immediate surgery and thus was negligent in the supervision of her medical care. The trial court granted the college summary judgment, and McNeil appealed. On appeal, the court affirmed the lower court's ruling, finding that the college had no legal responsibility to supervise McNeil's medical care following her accident since New York had rejected the in loco parentis doctrine and thus, owed her no duty. Also, evidence did not show that the program administrator was aware of the physician's recommendation.

In another case involving medical care and access to a student, Amy Fay was participating in a three-week international study-abroad trip in Peru sponsored by Thiel College when she became ill. ${ }^{27}$ She received care from a medical clinic in Cuzco, but was left in the care of a Lutheran missionary not

${ }^{23}$ Bloss v. Univ. of Minnesota, 590 N.W.2d 661 (Min. Ct. App., 1999).

${ }^{24}$ Evans, supra note 18.

${ }^{25}$ Rishabh R. Jain, "When Study Abroad Ends in Death, US Parents Find Few Answers," Wash Post, July, 7, 2017. https://beta.washingtonpost.com/world/the_americas/when-studyabroad-ends-in-death-us-parents-find-few-answers/2017/07/06/8f435116-62b1-11e7-80a28c226031ac3f story.html?outputType $=$ amp

26667 N.Y.S.2d. 397 (N.Y. App. Div. 1998).

${ }^{27}$ Fay v. Thiel Coll., 2001 WL 1910037 (Pa.Com.Pl. 2001). 
affiliated with the college. The three faculty members continued on their trip with the other students, while Ms. Fay underwent an unnecessary appendectomy. The plaintiff had asked before the surgery whether it was absolutely necessary, to be transferred to a hospital in Lima, and to call her parents. All of these requests were denied. After the surgery, the surgeon and anesthesiologist sexually assaulted her while she was conscious but under local anesthetic. Ms. Fay sued the college alleging faculty negligence, claiming that if they had not left her alone, she would not have suffered her injuries.

The college claimed that the plaintiff had signed a liability waiver before the trip and asserted that they had no legal duty to her. However, the trial court denied the college summary judgment and found that the liability waiver constituted a contract of adhesion - in other words, it was drafted by the college, the party with power, and both parties agreed that the waiver was presented on a "take it or leave it basis," meaning that the plaintiff did not have any choice but to sign the waiver. As a result, the consent form that the student signed created a "special relationship" between the student and the college, which created a duty. Faculty supervisors had a duty to secure whatever treatment was necessary. Although the college tried to argue that the surgeon's and anesthesiologist's actions were a superseding cause, and even if the faculty were present, they would have been unable to prevent the sexual assault, the court rejected this claim and sent the case to a jury trial. The jury found that the college breached the duty of care owed to the student and that the faculty should have secured and overseen her medical treatment.

\section{Discrimination in International Settings}

Differences in infrastructure and transportation can make movement and access challenging for students with physical disabilities, but the lengths to which an institution is legally obligated to go in order to facilitate study abroad is not entirely settled. The Office of Civil Rights (OCR) has indicated that Title II of the Americans with Disabilities Act (1990) ${ }^{28}$ and Section 504 of the Rehabilitation Act (1973) ${ }^{29}$ do not apply in international settings; however, there are a variety of other federal and state laws which create some legal liability for institutions, particularly if the student can prove that the program failed to provide accommodations that were promised. Although case law is not robust in this area, there is some indication that a student may be able to pursue legal recourse if they can demonstrate a breach of contract or fiduciary duty. Thus, it is important for U.S.-based higher education institutions operating abroad to consider variability in interpretations of the "duty of care" required at that location, and to be aware that claims of breach to such duty are being taken as serious claims in an increasing number of countries. ${ }^{30}$

\footnotetext{
2842 U.S.C. $\S \S 12101-12213$ (2013) (amended 2008).

2929 USC §701, Pub. L. No. 93-112, 87 Stat. 394 (1973).

${ }^{30}$ Rhodes \& Ludeman, supra note 17
} 
For example, in Bird v. Lewis \& Clark College, ${ }^{31}$ a wheelchair-bound student sued the college and was awarded $\$ 5,000$ in damages after participating in a study-abroad program in Australia where she had been unable to participate in several activities and experienced difficulties accessing lodging and bathroom facilities without the assistance of others. When the college learned of Bird's disability, the Australian company that made arrangements indicated that the program could be revised to accommodate her disability. The on-site faculty host even met one-on-one with Bird to discuss her needs for living accommodations and medication needs. Bird was informed at that time that while she would not be able to participate in several activities of the program, adequate accommodations would be available, alternative activities would be provided, or adequate facilities would be available. However, upon arrival there was inadequate wheelchair access at approximately twenty-two locations, including steep ramps and curbs, improper shower and toilet access, and no elevators. As far as field activities, she was not able to participate in a number of them due to ground elevation and improper accommodations and facilities. The college asserted that it appropriately accommodated Bird's disability because it paid for taxis, booked a flight while classmates took a train, arranged for a transport van, paid two students to be her helpers, and purchased a special sleeping cot, among other actions.

At the trial court, Bird alleged violations of Title III of the ADA, ${ }^{32}$ the Rehabilitation Act, ${ }^{33}$ breach of contract, breach of fiduciary duty, defamation, negligence, fraud, negligent misrepresentation, and intentional infliction of emotional distress. Bird also asked that the college should be prevented from releasing her grades, and be required to change its overseas program to prevent the repetition of her experience in the future. The trial ruled against Bird on summary judgment of her claims of defamation and intentional infliction of emotional distress. The remaining claims were tried in court. The jury found that the institution had provided reasonable accommodations, but that the college had breached its fiduciary duty based upon specific reassurances the program had made to the student. On appeal, the case offered illustration of the importance of careful planning and accurate assessment of whether the institution can provide reasonable accommodations, as well as clear articulation of such accommodations for students with disabilities, since it found there was a "special relationship" between Bird and the college.

In a case involving Title IX of the Educational Amendments, ${ }^{34}$ six female students from Eastern Michigan University (EMU) claimed gender discrimination and sexual harassment against the university. The plaintiffs were forced to leave a five-week summer study-abroad program sponsored by EMU in South Africa because of the actions of three male students, two of whom were participating in the program and the third was the faculty supervisor's assistant. The

31303 F.3d 1015 (2002), cert. denied, 538 U.S. 923 (2003).

3242 USCS $\S 12181$ et seq.

3329 USC § 794 et seq.

${ }^{34} 20$ USC § 1681 et seq. 
female students left the program early after repeated incidents of harassment by the three male students that involved a violent altercation. After repeated attempt to involve the faculty supervisor to no avail, the female students left. ${ }^{35}$

The question was whether Title IX could be applied to incidents outside of the United States and if the court had subject matter jurisdiction over these claims. The court found in the affirmative-Title IX has extraterritorial application outside the U.S. - citing that Congress intended for Title IX to apply to every single program of a university or college, including study abroad. EMU argued that under Title IX, it states " $[n]$ o person in the United States ..." shall be discriminated on the basis of sex. The court cited Gebser v. Lago Vista Independent School District, ${ }^{36}$ stating that Title IX's purpose is "to avoid the use of federal resources to support discriminatory practices and to provide individual citizens effective protection against those practices. ${ }^{37}$ As a result, the court found that to limit Title IX jurisdiction over study-abroad programs would be limiting a female's opportunity to participate in these programs and would allow for discrimination abroad when it would be illegal in the U.S.

\section{Enrollment of International Students in the U.S.}

With the gradual decline of state financial support for public higher education, many institutions have turned to the enrollment of international students to meet the financial needs of the institution and to diversify its student body ${ }^{38}$ While the number of international students in the U.S. has increased every year, both the amount of that increase and the number of enrolled students have fallen every year since the 2016 elections. ${ }^{39}$ Recruitment and enrollment of international students remains a high priority and important to the mission of U.S. higher education, but there are potential legal concerns for institutions to consider. A common theme of allegations from international students against institutions is discrimination based on national origin. Their complaints have also included breach of contract; due process violations; negligence; and discrimination, generally based on race, sex, or age.

${ }^{35}$ King, et al. v. Eastern Michigan University, 221 F. Supp. 2d. 783 (E.D. Mich. 2002).

${ }^{36} 524$ U.S. 274 (1998).

${ }^{37} \mathrm{Id}$. at 286-290.

${ }^{38}$ See generally Jane Knight, A Shared Vision? Stakeholders' Perspectives on the Internationalization of Higher Education in Canada, 1 J. STUdies InT'L Educ. 1 ( 1997), and Altbach and Knight, supra note 10.

${ }^{39}$ Open Doors 2018, InstituTe OF INT'L Educ. (Nov. 13, 2018), available at https://www.iie.org/ en/Research-and-Insights/Open-Doors/Data. 


\section{Discrimination Based on National Origin}

The U.S. Supreme Court has focused on the rights of foreign students, ${ }^{40}$ and it has found that resident aliens - nonimmigrant persons - are a suspect class. ${ }^{41}$ While most lawsuits from international students claimed discrimination based on national origin, student-plaintiffs often failed to meet the legal definition of discrimination. The following cases illustrate the legal definition needed to meet the standard of discrimination, even if some of the plaintiffs in the following cases are not necessarily international students on an F-1, J-I, or similar visa. In Ikekwere v. Governing Board of Foothill-deAnza Community College District, ${ }^{42}$ the court granted the defendant's motion for summary judgment. Ikekwere began taking classes at the community college in January 2004 in hopes of being admitted to the college's respiratory therapy program. After taking and passing prerequisite classes, Ikekwere was admitted into the program, which consisted of both classroom and clinical evaluations. In order to remain in good standing in the program, students may not receive a grade lower than " $\mathrm{C}$ " in core respiratory courses, an " $\mathrm{F}$ " in any required program course, nor have three "marginal evaluations." A marginal evaluation is considered to be similar to a failing grade that can arise from failure of performance in the didactic classroom or behaviors in the clinical environment. In May 2006, Ikekwere received a marginal evaluation from a clinical assignment, his third since he had failed the same course twice previously. After being notified of his dismissal, he grieved unsuccessfully with the college and exhausted his administrative remedies. In 2008, Ikekewere filed complaints alleging discrimination based on his race, national origin, and disability. Unfortunately, he was unable to show that a similarly situated non-Black Nigerian was treated differently. While Ikekwere did compare his situation to another Caucasian student, that student only received two marginal evaluations and not three.

Similarly, in Senu-Oke v. Jackson State University, et al. ${ }^{43}$ Senu-Oke was dismissed from his Executive Ph.D. program in August 2004. Shortly thereafter, he filed suit against the university alleging violations of his civil rights under

${ }^{40}$ See generally Nyquist v. Mauclet, 432 U.S. 1 (1977) (Justices found that a New York state law that prohibited resident aliens from receiving state-sponsored scholarships was unconstitutional), and Toll v. Moreno, 458 U.S. 1 (1982) (Supreme Court ruled in favor of domiciled nonresident aliens on G-4 visas - those issued to employees and family members of those employed by an international organization. Policy prohibiting in-state resident tuition from these domiciled nonresident aliens was unconstitutional). It is important to note that while these U.S. Supreme Court decisions examined and afforded rights to resident aliens, Section 505 of the Illegal Immigration Reform and Immigration Responsibility Act of 1996 (IIRIRA) no longer permits this practice.

${ }^{41}$ See generally Graham v. Richardson, 403 U.S. 365 (1971) (Justices finding that new York law barring resident aliens public benefits unconstitutional), and Tayyari v. New Mexico State Univ., 495 F.Supp. 1365 (D.N.M. 1980) (Iranian students argued violation of the Equal Protection Clause of the 14th Amendment for not enrolling students due to the U.S. hostage crisis in Iran; the court ruled in favor of the students).

422010 U.S. Dist. LEXIS 47288 (N.D. Cal. 2010).

${ }^{43}$ No. 3:06-cv-468, 2008 U.S. Dist. LEXIS 13264 (D. Miss. 2008). 
42 U.S.C. $§ 1983$ based on discrimination due to his national origin, Nigeria, and not being afforded due process. The Executive Ph.D. program required him to attend an in-person orientation. While Senu-Oke booked a flight and checked into his hotel, he had to return to his home state of Illinois before his Executive Ph.D. orientation took place in Mississippi. He left without notifying the program or faculty; because he failed to attend the orientation program and failed to register, the university claimed he breached his partnership agreement with the institution. The federal district court found in favor of the defendants and granted summary judgment to dismiss the plaintiff's federal claims. The matter was remanded to the state court to litigate state laws. Pertinent to this topic is that the court found there was no intentional discrimination against Senu-Oke based on his national origin and, given the early dismissal, he had very little or no property interests, which would only require minimal due process.

It is important to note that in order to succeed on a claim of discrimination, plaintiffs must meet the legal definition of discrimination; ${ }^{44}$ however, trying to find a similarly situated person to show discrimination can be a real challenge. In Amir v. Marquette University, ${ }^{45}$ an Iranian native claimed that he was unfairly dismissed due to poor academic performance. He appealed his case twice, but he was unsuccessful because he could not provide sufficient evidence that the Caucasian classmate to whom he compared himself was similarly situated.

\section{Issues of Academic Integrity}

Issues of academic integrity can be complex for international students since views on plagiarism and cheating in the United States can differ from those in other countries and cultures. For example, in Alkahadra v. Harvard, ${ }^{46}$ the Saudi native was dismissed for plagiarism when she memorized a journal article and reproduced it nearly verbatim on an exam question. She stated that it was an honest mistake and that in Saudi Arabia, memorization was valued.

Issues of plagiarism among international students have been debated on college campuses. How much latitude should students be given to adjust to the new culture? In 2007, thirty-four business students at Duke University were punished for cheating. A lawyer for sixteen Asian students claimed that their punishment was too harsh compared to penalties for non-Asian students, and that cultural bias played a role. ${ }^{47}$ During an appeal to the Duke judiciary committee, the lawyer argued that the Asian students did not understand the

${ }^{44}$ See also Nguyen v. University of Massachusetts, 72 Mass. App. Ct. 1107; 889 N.E.2d 981; 2008 Mass. App. LEXIS 741 (July 11, 2008) (discrimination based on political beliefs is not a protected class).

452009 Wisc. App. LEXIS 806; 2009 WI App 174; 322 Wis 2d 572; 776 N.W. 2 d 287.

${ }^{46}$ No. 1:10-cv-11083-NG (D. Mass. filed June 25, 2010; dismissed Oct. 25, 2010). See also Adam Gaffin, Saudi dentist alleges discrimination in lawsuit against Harvard, Universal Hub (Jun. 29, 2010), available at https://www.universalhub.com/2010/saudi-dentist-alleges-discriminationlawsuit-again.

47 See generally Associated Press, Lawyer: Cheating case hits Asians hardest, DiverseEducation. сом (May 22, 2007), available at https://diverseeducation.com/article/7363/. 
honor code and were pressured into confessing without understanding the consequences or their U.S. Fifth Amendment right not to incriminate themselves. The penalties were upheld.

A 2006 investigation at Ohio University discovered extensive plagiarism among international students' theses in the mechanical engineering department and placed blame on the faculty for not enforcing academic integrity. Another student discovered that multiple masters' theses over many years carried the same language, and most if not all of these theses were submitted by international students. ${ }^{48}$ The theses were either revoked or removed from the library until revisions were made. This scandal resulted in the demotion of one professor and the termination of another. Both sued the university for defamation, among other charges, claiming that the students had committed the lesser of two kinds of plagiarism - failing to include quotation marks around quotes. The students did cite the author in endnotes. A more serious offense would have been to use the information without citing the author. On appeal, the Ohio Court of Appeals held that generally the professor did not have actionable claims for defamation. ${ }^{49}$

\section{Miscellaneous Issues}

A variety of other legal issues relate to the prejudice and stereotype that some have for international students. In Delacroix v. Santa Clara University, two Chinese students complained about a business professor for singling them out for being late seven minutes to class, speaking too fast, and making them read the National Enquirer. The professor sued the university after learning about the investigation against him, claiming that the institution did not do a proper investigation because it did not want to stifle its pipeline of Chinese students. ${ }^{50}$ Similarly, in Shakir v. Rend Lake College, the plaintiff sued for retaliation and discrimination when passed over for a promotion in favor of a Caucasian man. Pointing to correspondence referring to his English-language skills, unethical behavior for practicing his Muslim religion, speaking Arabic during school hours, and hiring a non-English-speaking colleague, the plaintiff cited a "hostile and discriminatory atmosphere" at the college. ${ }^{51}$ Given these few examples, it is critically important that institutions train and educate faculty and staff on the growing legal and educational implications of having international students on campus.

${ }^{48}$ Robert Tomsho, Student Plagiarism Stirs Contraversy at Ohio University, Wall StReET J. (Aug. 15, 2006), available at https://www.wsj.com/articles/SB115560632839035809.

${ }_{49}$ Mehta v. Ohio Univ., 194 Ohio App.3d 844, 958 N.E.2d 598, 274 Educ. L. Rep. 670 (July 14, 2011).

502008 WL 616289 (filed in Santa Clara Cty. Super. Ct. June 8, 2005; settled Sept. 5, 2006).

512010 WL 432262, 3:08-cv-00768-DRH (S.D. Ill. Feb. 8, 2010). 


\section{International Treaties and Agreements}

International agreements and treaties can have legal implications for institutions in a variety of areas. For example, the World Trade Organization's Agreement on Trade-Related Aspects of Intellectual Property Rights (TRIPS) prohibits the unauthorized copying of copyrighted works, such as textbooks. Other copyright agreements include the Berne Convention and the Universal Copyright Convention. In addition to textbooks, these agreements may apply to faculty research, patents, trademarks, and copyrights. It is critical for institutions to understand and determine how work created abroad or with foreign faculty is owned and credited.

The Bologna Agreement, also known as the Convention on the Recognition of Qualifications Concerning Higher Education in the European Region — signed by fifty countries, including the U.S.—created a unified system for evaluating and recognizing foreign degrees and credentials. Beside the Bologna Agreement, other EU regulations also impact international higher education; for example, the European Union's (EU) General Data Protection Regulation (GDPR) has implications for foreign institutions serving those in EU member states, whether it is a physical or online presence. The GDPR protects personal information of EU residents and provides certain rights to access and delete personal data acquired by organizations. The General Agreement on Trade and Services (GATS), signed in 1995, helped to make it easier to offer services across borders, including education. Given the variety of these international legal issues, institutional leaders are challenged to be aware, create a plan, and communicate.

\section{Conclusion}

As internationalization and globalization of higher education continue, it is ever more important for higher education and student affairs professionals, faculty, and leaders to understand the vast breadth of legal issues that arise. International students add diversity and vibrancy to our campuses, and our institutions must continue to do a better job of inclusion and engagement.

\section{Discussion Questions}

1. How have internationalization and globalization of higher education evolved?

2. What are top legal issues for institutions to consider in study-abroad programs?

3. Given the legal issues brought by international students studying in the U.S., what should U.S. higher education institutions do to respond? 